\title{
An Analysis of Willy Loman's Tragedy in Death of a Salesman
}

\author{
Jinying Zhao \\ Col. of Humanities and Law, North China Univ. of Tech., 100144, Beijing, China \\ zhaojinying90v@163.com
}

Keywords: Willy Loman; A personal tragedy; A family tragedy; A social tragedy; Reflection

\begin{abstract}
Death of a Salesman, is regarded as one of the three most remarkable tragedies in America. The author, Arthur Miller, emphasized that the drama should not only express characters' psychological and subjective world, but also convey the real complex social situation. It has successfully characterized the tragedy of a common salesman in America. It is significant to anal size why Willy committed suicide. This paper managed to analyze causes of Willy Loman's death, namely, mainly from three perspectives: a personal tragedy, a family tragedy and a social tragedy. In fact, the society Willy lived was familiar with our present era, people are also facing with similar problems Willy had at that time. Hence, through analyzing Willy's death, we could discover that his life revealed some social problems behind personal and family tragedy in current society, arousing our reflection on ethical and moral standards in money-oriented society. And the most important thing is to know ourselves.
\end{abstract}

\section{Introduction}

Along with Tennessee Williams and Eugene O'Neill, Miller was one of the best-known American playwrights after the Second World War. Among his works, Death of a Salesman made a sensation since it was performed in 1949, which secured his reputation as one of the nation's foremost playwrights.

Set in New York and Boston in the late 1940s, this play describes the tragedy of Willy Loman, an average traveling salesman, in his sixties, could never familiarize himself with "American Dream", nor could he realize the brutal commercial world, always dreaming of the impractical future for his two children. His love for his two sons with incorrect approaches ruined their life. His final suicide, a sacrifice for his family, especially for the future of his elder son, Biff, however, he could not fully convey his love for his family members.

Scholars abroad and at home have done much research about Death of a Salesman, from various perspectives. Many of them focused on the study or critics of the tragedy of the family, the father-son conflicts. Ke Jianhua pointed that Willy Loman's tragedy is caused by the conflicts between ethical dream (American dream) and commercial jungle law (morality alienation). [1] It was from the macro level, but the tragedy was not that simple. Through analyzing the realistic features in literature, character, stage design and language, Wang Qian argued that Death of a Salesman is a play in which realism is perfectly used.[2] It mainly analyzed the realism, language features, stage design, not focusing on the protagonist's death.

Therefore, this paper continues to explore more detailed causes; Willy Loman's death, we think, was not merely his personal tragedy, but also the family tragedy and the social tragedy, as well.

\section{Willy Loman's Death as a Personal Tragedy}

Dishonest and Hypocritical. As a common people, Willy Loman longed for gaining others' respect, including his family, his neighbors and his brother. However, there was no need for him to utilize lies to conceal his failure. Dishonesty was the flaw of his personality. He told lies about how popular and respected he was in the town, and how important he was to New England, wanting to be adored and admired by his sons. In fact he was not that popular. 
When Willy went to borrow money from Charley and happened to meet Bernard, Bernard wanted to know how his old friend Biff was doing. Willy also told a lie. Biff was, in fact, obsessed with his job and his life, not having found a position in society.

Self-centered and Unable to Face the Reality. Willy was too self-centered and easily to lose temper, not allowing others to change his mind. Willy did not respect Linda and Biff at all. He wanted Biff to become a successful salesman, which Biff actually did not long for.

Willy owed his failure to his indecent clothes, unwilling to discover the real reasons for his failure. After being fired, Willy came to borrow insurance money from kind-hearted Charley, who offered Willy a job. Willy, however, refused to work for Charley. Working for his neighbor, maybe was better than being the road salesman. He preferred to be a salesman with little salary rather than work for Charley to get fifty dollars a week.

Holding False Values. As a salesman, Willy Loman focused on personal details over actual measures of success, believing that it is personality and not high returns that gain success in the business world. Just as he said in the play:

Willy: the man who makes an appearance in the business world, the man who creates personal interest, is the man who gets ahead. Be liked and you will never want.

Willy: Because you got a greatness in you, Biff, remember that. You got all kinds a greatness. ${ }^{[3]}$

Willy instilled the false values into his sons' mind. He strongly had faith in Buff's personal charm, ignoring to underline one's talent and diligence. There was no denying that Willy's personal flaw was one aspect of his tragedy, for his sticking to unacceptable traditional values.

\section{Willy Loman's Death as a Family Tragedy}

Conflicts between Willy and His Two Sons. Biff and Happy were Willy's beloved two sons. However, the main father-son conflict was between Willy and Biff. There were many reasons that triggered conflicts.

Father-son Betrayal. "In the eyes of Biff, Willy is an omnipotent hero. He admires Willy and treats him as an idol. For Willy, Biff is his proud just as the character of Apollo." [4] Willy hoped that Biff could follow his plan, be admitted into university or go into business. To Biff's disappointment, he failed in the graduation exam. He thought it was not only his failure but also a strike to his father. He prepared to go to university, especially for his father. So he went to Boston to turn to him for help. However, Biff discovered the secret about his father that shocked him. His father had an affair with a woman in the hotel. He was so frustrated and flew into in a rage.

Willy's hero image in son's mind was fragmented. Willy turned out to be a hypocrite and a "liar". Since then, Biff's spiritual pillar collapsed. He burned his favorite football shoes of the University of Virginia and refused to attend summer session, giving up the opportunity of going to university and embarked on a completely different way. Without Willy's betrayal, maybe Biff would have different destiny.

Father's Inappropriate Education. Happy, an attractive and powerful man, was Willy's second son. He tried to attract Willy's attention and he desired for father's favor. But Willy gave Biff more attention, he had never realized what happened and just ignored Happy's feeling.

"As unfortunate as it is, there are many instances where a father favors one son over another, which leads to social conflicts within the less-favored son. In most cases if the elder son is favored, the younger son will be ignored."[5]

Parents should educate children that it is shameful to be a thief. But Willy did not prevent and even instigate Biff's theft; he did not punish Biff for "borrowing" a football from school. Under the twisted values and education, Biff became misdemeanant. If Willy had stopped Biff and educated him, things may become different.

"In material society, a person who is successful does not depend on his popularity. Under Willy's educational philosophy, Biff pursuits the so-called personal charm and ignores his own talent. There is no doubt that his failure is doomed."'[6] 
Therefore, family education has a great impact on children growth and development. Willy, to some extent, was not a good father. He instilled twisted dream of being a successful salesman into their mind, not teaching his sons right values, not underlining the importance of study.

Different views of American Dream. When he was young, Willy was educated by the principle of "American Dream", that was to work hard to reach one's goal, he admired his father and brother Ben's diligence and success in the jungle, while he was determined to chase his success in a big city. Just as Eugene O'Neill said, "We talk much about American Dream and propagate it across the world. To the majority, does not it mean to pursue the material success?"[7] He did have ambition, but could not understand the truth of the business and his real needs. He expected to gain more chance by his good personality and other's respect. Hence, Willy wanted his two sons to live in wealthy and decent life, but their dreams collide, namely, city to country, reality to idealism. The point was that they could not confront the reality.

Biff, an idealistic boy, was aware of the fact that he did not belong to the business world. He was disgusted at Business community preferring natural life. Biff thought it was worthless in the way of life of the city. When he came back home to readjust himself, Willy regarded it as a failure. The following conversation was Biff's inner voice.

Biff:(with rising agitation): Hap, I've had twenty or thirty different kinds of jobs since I left home before the war, and it always turns out the same....... suddenly get the feeling, my God, I'm not get in anywhere! What the hell am I doing, playing around with horses, twenty-eight dollars a week! I'm thirty-four years old, I ought to be make my future. That's when I come running home. And now, I get here, and I don't know what to do with myself. (After a pause)I've always made a point of not wasting my life, and every time I come back here I know that all I've done is to waste my life. ${ }^{[3]}$

"Happy had never fully come to realize that phony part of his father and his father's dreams. Moreover, he had more fully than Biff accepted his father's dreams." [8] He managed to pursue the American Dream. At the end of the play, he still was blind to recognize himself, but determined to stay in the city and carry out his father's dream by becoming a top businessman.

Conflicts between Willy and Linda. Linda loved Willy very much. Although Willy disrespected her even betrayed her, she was totally obedient to Willy, dare not talk with him.

Biff: Did you have it taken off?

Linda: I'm-I'm ashamed to. How can I mention it to him? Every day I go down and take away that little rubber pipe. But, when he comes home, I put it back where it was. How can I insult him that way? I don't know what to do. I live from day to day, boys. I tell you, I know every thought in his mind. It sounds so old-fashioned and silly, but I tell you he put his whole life into you and you've turned your backs on him. ${ }^{[3]}$

On the surface, there was no conflict between Willy, the sinful and moody husband, and Linda, the loving and patient wife. But at a deep level, it was partly the conflict between them that leads to the problems of the family. They cannot communicate with each other very well. Willy suffered a lot physically and spiritually on his trip or his work, his patient and considerate wife could not share the pressure with him. She just mentioned casually the bill they had to pay and carefully accommodated the father-son conflict. She did not try changing her husband's twisted values, nor did she prevent the breakup of the family at last. It was the tragedy of love and family.

\section{Willy Loman's Death as a Social Tragedy}

Willy was influenced by the concept of Darwin "The origin of species", the survival of the fittest. However, the real society was not that fair to everyone, especially to those from middle-low class. 
Howard: We have only got a half-dozen salesman on the floor here.

---: No, but it is business, kid, and every body's gotta pull his own weight.

Willy: I put thirty-four years into this firm, Howard, and now I can't pay my insurance! You can't eat the orange and throw the peel away-a man is not a piece of fruit! ${ }^{[3]}$

Willy was the victim of society, particularly a victim of a harsh economic system that first used and then discarded him. At that time, under the influence of money worship and various desires, people, especially, the capitalists would like to try every means to guarantee their survival and success in society. The employers were rather exploitative, who regarded employees as pieces of fruit, eating the fruit and throw the peel away. Regardless of how much sacrifice Willy has made for the company, his boss merely cared about Willy's current values and refused to provide him one more chance.

\section{Conclusion}

"This play helps Miller to reach the pinnacle of his writing career, he dedicated a lot in writing this novel, who combined in his works social awareness with deep insights into personal weaknesses of his characters".[8] This paper mainly analyzed the causes of Willy's death from three aspects, a personal tragedy, a family and social tragedy.

Willy never realized that he lived in a world of illusions and dreams. He became worse due to the enormous gap between dream and reality, thus it lead to the final tragedy.

Just as Miller said, "To Willy, only social status, power and sense of triumph are significant. He regarded the dazzling light reflected by the urban roof as brightest stars in the sky.'[10] Willy's twisted view of dreams and values ruined his life, as well as his family. He was not merely pitiable. His tragedy could arouse not only our sympathy and pity but also awakening and introspection.

Living in the contemporary society with intensified competitions, it is better for everybody to know ourselves, to keep paced with the rapid-developing society, pursuing what we really need, dedicating to our goals, rather perplexed with the so-called success.

\section{References}

[1] ke Jianhua. On the Ethical conflicts in Death of a Salesman [J]. Foreign Literature Research, 2010, 04: 110-116.

[2] Wang Qian. Realistic features of the Death of a Salesman [D]. Hebei Normal University, 2012.

[3] Miller, Arthur. Death of a salesman [M]: New York: Penguin Books, 2000.

[4] Wang Rui. Interpretation of Oedipus Complex in Death of a salesman [J].Anhui Literature( second semimonthly), 2012,05:36-37.

[5] Han Xue. The development of Father-Son Relationship Topic in Arthur Miller's All My Sons and Death of a salesman[D]. Master's thesis in Anhui University, 2009.

[6] Liu Hui. A study of Family Problems in Arthur Miller's Death of a salesman [D]. School of Foreign Languages Southwest University, 2011.

[7] Bowen, Croswell. The Curse of the Misbogotten: A Tale of the House of O' Neill. Trans. Chen Yuan. Hangzhou: Zhe jiang Arts Publishing House, 1988.

[8] Hong Yungao. On the Disillusionment of Willy Loman's Dream in Death of a Salesman [J]. Anhui University of Technology, 2006, 3: 77-81.

[9] Zhang Yun. Arthur Miller and Death of a Salesman [J]. Foreign Literature, 1994,(6):85-92.

[10]Nie Zhenzhao. "The Old Man and the Sea and the Jungle Law" Foreign Literature Review3 (2009): 80-89. 